\title{
Surface Remelting of Mold Inserts Made of NC11 Steel
}

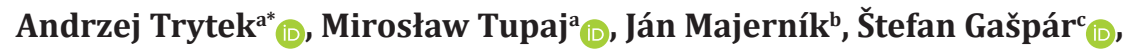 \\ Wiktoria Zbyrad-Kołodzieja ${ }^{\mathrm{a}}$, Karol Łysiak ${ }^{\mathrm{a}} \mathbb{C}$
}

\begin{abstract}
${ }^{a}$ Rzeszow University of Technology, The Faculty of Mechanics and Technology, Stalowa Wola 37-450, E. Kwiatkowskiego 4, Poland ${ }^{\mathrm{b}}$ The Department of Mechanical Engineering, Faculty of Technology Institute of Technology and Business in České Budějovice, Okružní 517/10, 37001 České Budějovice, Czech Republic

${ }^{\mathrm{c}}$ Faculty of Manufacturing Technologies of the Technical University of Kosice with a seat in Prešov, Bayerova 1, 08001 Prešov, Slovak Republic

*email: trytek@prz.edu.pl
\end{abstract}

(C) 2020 Authors. This is an open access publication, which can be used, distributed and reproduced in any medium according to the Creative Commons CC-BY 4.0 License requiring that the original work has been properly cited.

Received: 27 November 2019/Accepted: 20 February 2020/ Published online: 30 March 2020

This article is published with open access at AGH University of Science and Technology Press

\begin{abstract}
In the study presented in this paper, the effect of a concentrated heat stream on geometry, microstructure, and hardness of superficial remeltings on NC11 steel is examined. The material is used for disposable mold inserts exposed to intensive abrasive wear in the course of the press-molding of hard aggregate stampings for refractory bricks. As a result of local remelting, the hardness of the steel surface increased and its microstructure was altered. Macro- and microstructure of the remelted areas was examined with the use of optical microscopy and measurements of remelting area geometry were carried out for different parameters of the remelting process. Hardness measurements were taken in the remelting area and in the heat-affected zone. The state of stress in the material before remelting and in the remelted area was also evaluated.
\end{abstract}

\section{Keywords:}

NC11 steel, mold inserts, concentrated heat stream, metallographic tests

\section{INTRODUCTION}

Bricks of refractory materials used to build foundry furnaces are molded from aggregates characterized by a high degree of hardness. In the course of the process of press-molding stampings for the bricks, aggregate grains rub against the metal mold surface which results in its wear. The wearing effect is intensified because of the sharpness of grain edges moved repeatedly in the course of the aggregate compacting process. The molds in which the stampings of refractory materials are formed are made of cold-work alloyed steels. To reduce the manufacturing cost and overhauling period, molds are given the form of a body with molding cavities which are lined with replaceable inserts. In view of the intensity of the wearing process, the lining elements should be characterized by a high resistance to abrasive wear. As a result of the excessive wear of mold inserts, stampings of refractory material are prone to cracking and become unfit for the next production stage (firing). In view of stoppages and costs due to press retooling and replacement of the inserts, it became necessary to look for a solution enabling the extension of the service life of the components [1-8].

Extending the life of new machine parts is mainly by means of the use of new expensive materials and alloys and their heat treatment [9-13]. Repair of damage or the regeneration of parts of machinery worn as a result of operation usually involves supplementing the damaged area using powder spraying techniques or 3D printing [14-18]. The present authors' experience in the area of the local hardening of alloys with the use of a concentrated heat stream enabled them to advance the conclusion that, with the use of a laser beam, it would be possible to locally alter the microstructure of NC11 steel, increasing its hardness in comparison to the initial material, and thus extending the service life of the mold inserts [19-22]. 


\section{THE RESEARCH}

\subsection{Research material}

The tested material was NC11 steel containing about $12 \% \mathrm{Cr}$ (Tab. 1). The material is a high-carbon cold-work steel designated as NC11, X210CrW12, 1.2436, X210Cr12, or 1.2080. NC11 steel is used to manufacture parts of machines and devices which are required to show high resistance to abrasive wear, e.g. drawing dies, blanking tools, threaders, cutting tools, forming dies, and punches [23].

NC11 steel is used to fabricate insert for cavities of moulds forming ceramic bricks of refractory materials. The microstructure of NC11 steel comprises a metal matrix with very fine carbides as well as long and thick carbide precipitates. The microstructure of NC11 steel carbides include chromium to the extent of $44 \% \mathrm{Cr}$ and iron to $88 \% \mathrm{Fe}$, as well as manganese from about $0.15 \%$ to $0.29 \% \mathrm{Mn}$. The carbides differ in their shapes and lengths. The length of the carbides is from $2 \mu \mathrm{m}$, and can be as long as $120 \mu \mathrm{m}$. The structure of the matrix of NC11 includes $9 \% \mathrm{Cr}, 87 \% \mathrm{Fe}$ and $0.23 \% \mathrm{Mn}$ [4]. The microstructure of the NC11 steel used for the purposes of the present study is shown in its initial state in Figure 1.

Table 1

Chemical composition of NC11 steel [23]

\begin{tabular}{lccccc}
\hline $\begin{array}{l}\text { Element } \\
\text { Content, } \\
\text { \% wt. }\end{array}$ & $\mathrm{C}$ & $\mathrm{Mn}$ & $\mathrm{Si}$ & $\mathrm{P}$ & $\mathrm{S}$ \\
\hline $\begin{array}{l}\text { Element } \\
\text { Clem }\end{array}$ & $\mathrm{Cr}$ & $\mathrm{Ni}$ & $\mathrm{Mo}$ & $\mathrm{W}$ & $\mathrm{V}$ \\
\hline $\begin{array}{l}\text { Content, } \\
\text { \% wt. }\end{array}$ & $11.0-13.0$ & 0.35 max. & 0.20 max. & 0.20 max. & 0.15 max. \\
\hline
\end{tabular}
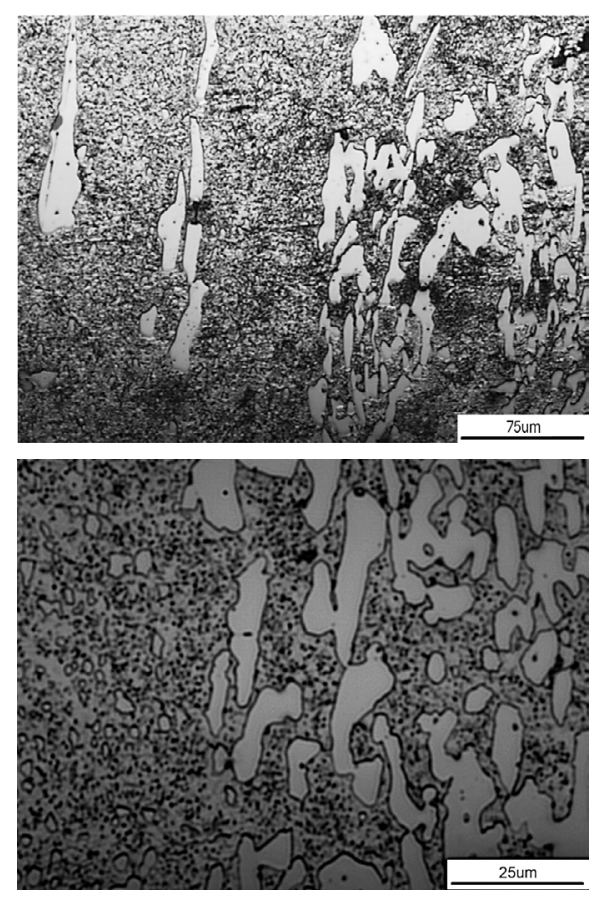

Fig. 1. A view of the microstructure of NC11steel; matrix and chromium carbides

\subsection{The test setup}

The setup for superficial remelting tests comprised an industrial booth equipped with a KUKA robot arm and a TruLaser ROBOT 5020 turnkey laser (TRUMPF) with the maximum power of $4 \mathrm{~kW}$ (diode laser with a wavelength of $1030 \mathrm{~nm}$, beam diameter $0.9 \mathrm{~mm}$ ). The setup is dedicated to developing and testing new technological processes as well as carrying out industrial operations such as welding, cutting, overlay welding, and heat treatment (Fig. 2). It is equipped with three independent heads intended for welding, cutting, and overlay welding (cladding).

a)

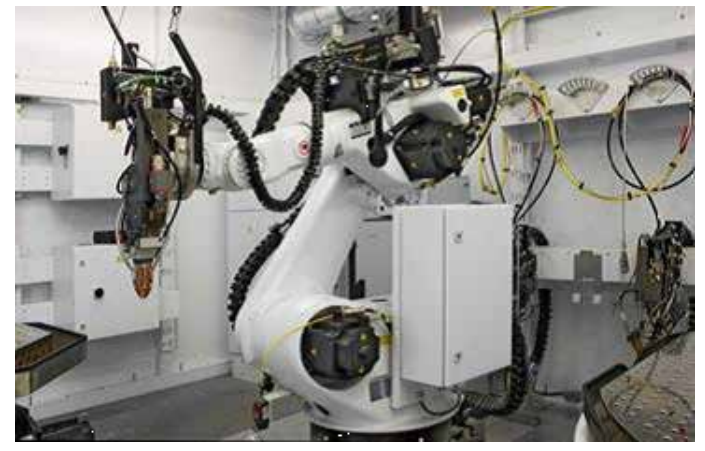

b)

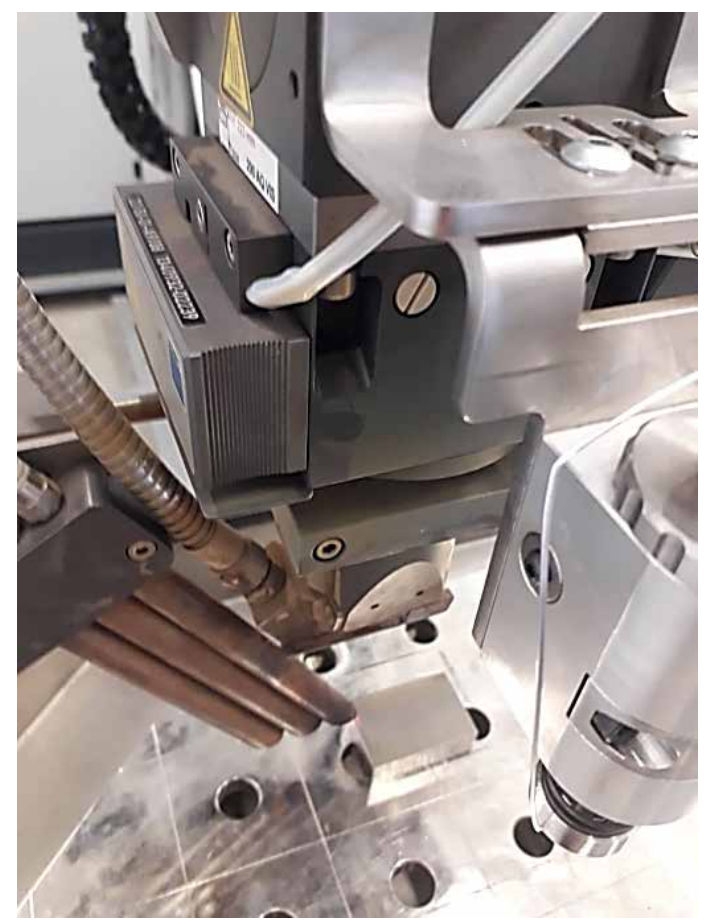

Fig. 2. A view of the test stand for remelting with a TruLaser ROBOT 5020. The laser stand is equipped with a KUKA robot arm (a), replaceable heads for: welding (b), cutting and powder welding

Due to the fact that a deep penetration of a small width is obtained with higher laser power, and these tests require surface hardening, low beam power was used. NC11 steel surface remelting tests were performed on specimens with dimensions $100 \mathrm{~mm} \times 100 \mathrm{~mm} \times 16 \mathrm{~mm}$. Three remelting runs were realized at the same laser power $P=500 \mathrm{~W}$ and at three different speeds of material surface scanning with a laser beam, namely $10 \mathrm{~m} / \mathrm{s}, 20 \mathrm{~m} / \mathrm{s}$, and $30 \mathrm{~m} / \mathrm{s}$. 


\subsection{Research methodology}

Examination of remelting areas on NC11 steel specimen surfaces consisted of macroscopic evaluation and measurements of remelting geometry. Moreover, metallographic examination was carried out, consisting of the observation of microstructures with the use of an optical microscope equipped with an advanced image analysis system, Multiscan v.08. Hardness measurements were taken with the use of a Nanovea nanoindentation microhardness tester. Figure 3 shows a schematic diagram according to which measurements of the remelting

a)

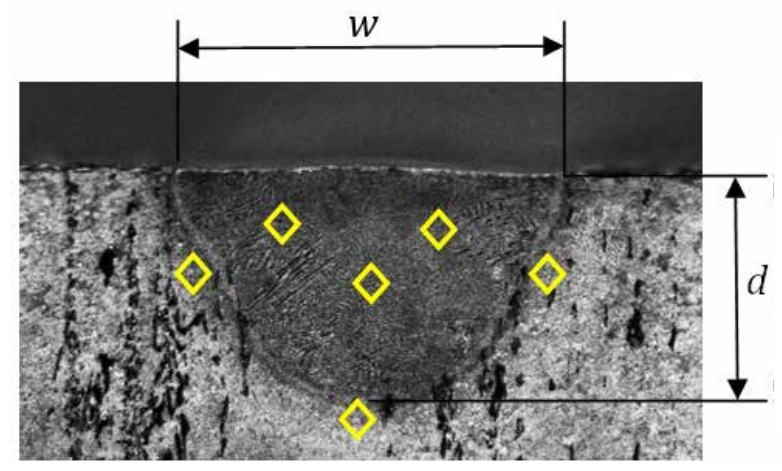

c)

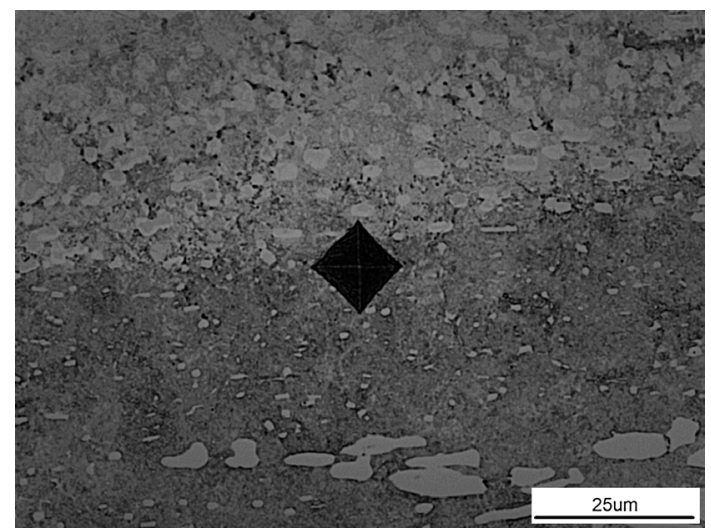

geometry and material hardness in the remelting area and in the heat affected zone (HAZ) were taken.

To determine their state of stress, remelting areas were also examined with the use of an Empyrean X-ray diffractometer (Malvern Panalytical) as shown in Figure 4, equipped with a five-axis table and a copper X-ray tube. Parameters of the scan for the XRD residual stress measurement were the following: start position $71.4890^{\circ} 2 \mathrm{Th}$., end position $76.4550^{\circ} 2 \mathrm{Th}$., step size $0.0260^{\circ} 2 \mathrm{Th}$., scan step time 1196 seconds. For the purpose of stress analysis, HighScore Plus and X'Pert Stress software were used.

b)

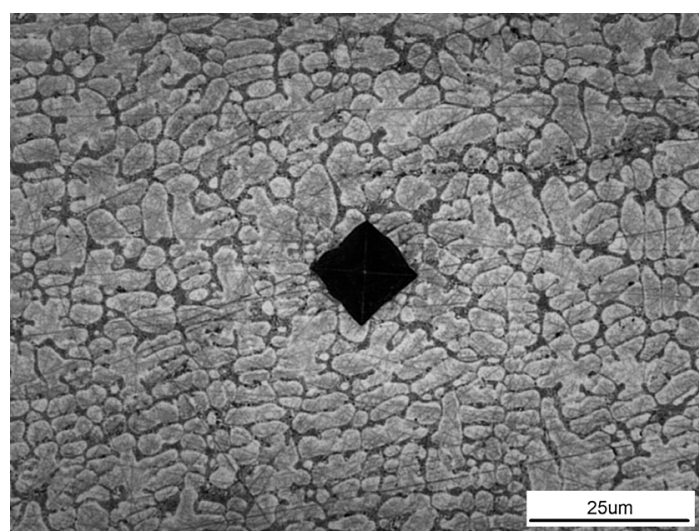

d)

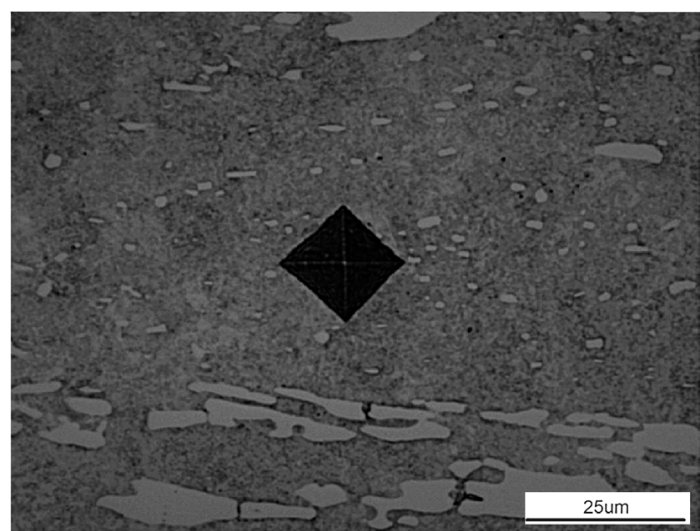

Fig. 3. Hardness measurements and melting geometry measurements: a) a schematic diagram ( $w$ - remelting width; $d$ - remelting depth; $\checkmark$ - hardness measurement points); b) examples of hardness measurements in the area of melting; c) examples of hardness measurements in the HAZ; d) examples of hardness measurements in the initial material

a)

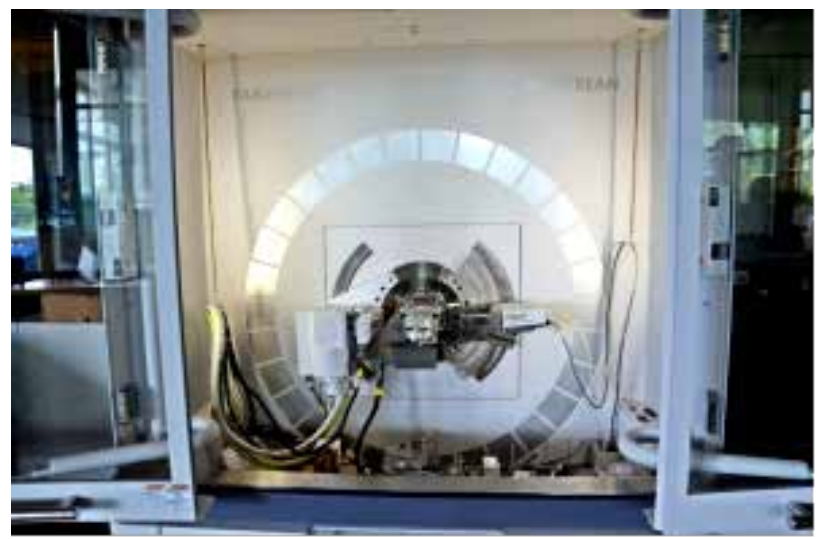

b)

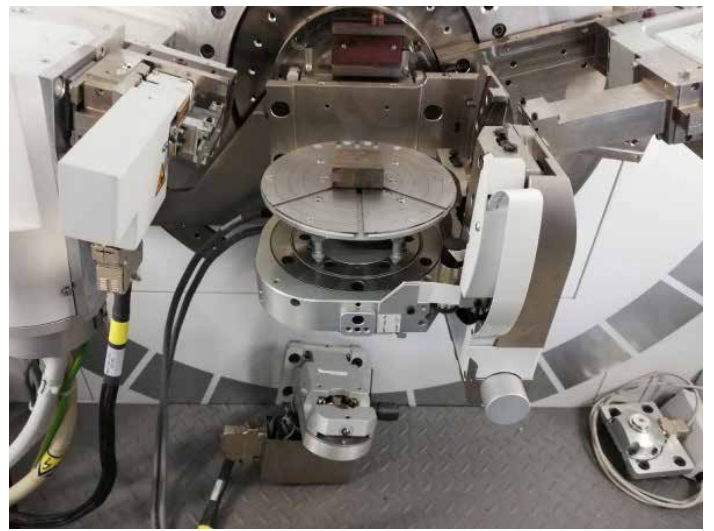

Fig. 4. The stress analysis setup: a) Empyrean PANalytical diffractometer; b) diffractometer table with a specimen 


\subsection{Research results}

Table 2 summarizes the results of the remelting geometry and hardness measurements taken in the remelting area and in HAZ and the values of stress determined in the remelting area, depending on the parameters of the process of surface remelting with laser.

The geometry of remelting areas formed on the NC11 steel specimen surface with a laser beam was different in each of the three tests. Both the width and depth of the remeltings decrease with the increase in the speed of scanning with the laser beam. The change in the melting geometry is primarily due to the amount of heat absorbed by the melted material. At constant beam power, the laser beam exposure time and, as a result, the amount of heat absorbed by the melting area, decreases as the scanning speed increases It was noted that in the remelting area, a dendritic microstructure was obtained. In the border region where the NC11steel parent material turns into the remelting area, large carbide precipitations were visible which dissolved in the course of remelting, along with the movement of the liquid metal pool.

In Figures 5-7, images of the macrostructure and microstructure of the remelting area and the heat affected zone (HAZ) on specimens of NC11 steel are shown, for different values of the speed of scanning with a laser beam.

Table 2

Results of the remelting geometry and hardness measurements in the remelting area and in HAZ depending on the parameters of the laser-induced surface remelting process

\begin{tabular}{|c|c|c|c|c|c|c|c|}
\hline \multirow{2}{*}{ No. } & \multicolumn{2}{|c|}{ Laser beam parameters } & \multicolumn{2}{|c|}{ Remelting area geometry } & \multirow{2}{*}{$\begin{array}{l}\text { Stress, } \\
\text { MPa }\end{array}$} & \multicolumn{2}{|c|}{$\begin{array}{c}\mathrm{HV}_{0.3} \text { hardness average } \\
\text { value in the area of: }\end{array}$} \\
\hline & $\begin{array}{c}\text { Power, } \\
\text { W }\end{array}$ & $\begin{array}{c}\text { Scanning speed, } \\
v_{s^{\prime}} \mathrm{mm} / \mathrm{s} \\
\end{array}$ & $\begin{array}{c}\text { Width, } \\
\text { mm }\end{array}$ & $\begin{array}{c}\text { Depth, } \\
\text { mm }\end{array}$ & & Remelting & HAZ \\
\hline 1 & 500 & 10 & 0.807 & 0.368 & -403.9 & $505 \pm 5$ & $580 \pm 6$ \\
\hline 2 & 500 & 20 & 0.761 & 0.290 & -383.9 & $531 \pm 6$ & $615 \pm 7$ \\
\hline 3 & 500 & 30 & 0.589 & 0.175 & -348.5 & $552 \pm 6$ & $643 \pm 7$ \\
\hline 4 & \multicolumn{4}{|c|}{ Initial material } & -138.6 & \multicolumn{2}{|c|}{$250 \pm 4$} \\
\hline
\end{tabular}

a)

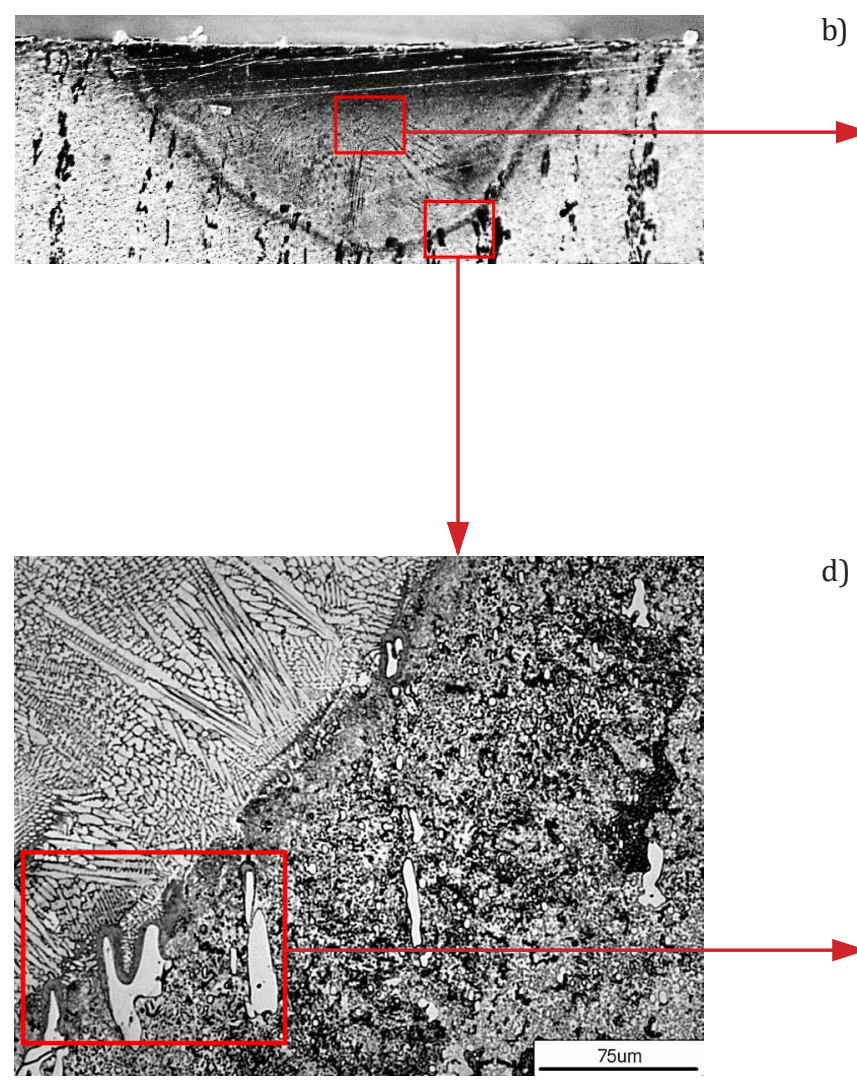

b)

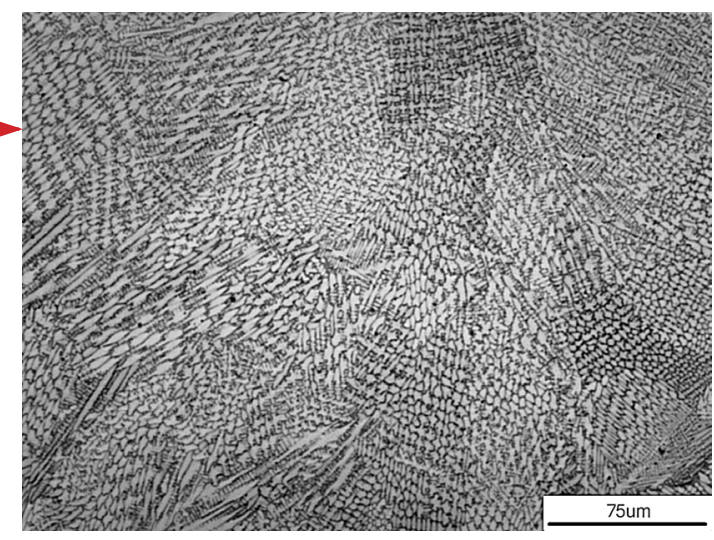

d)

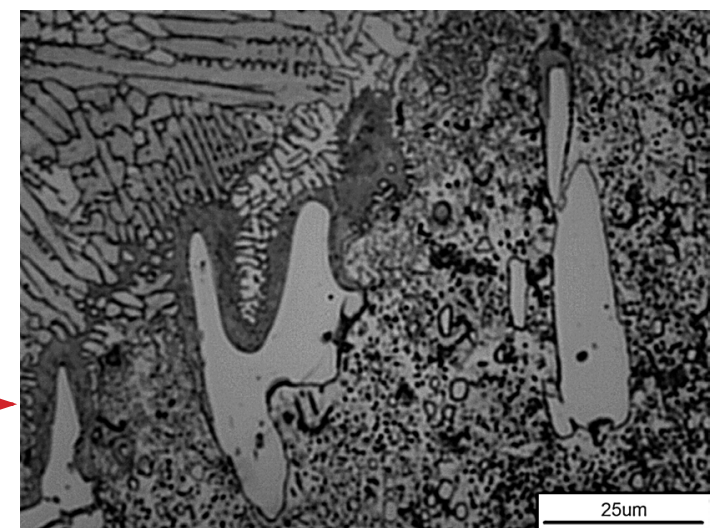

Fig. 5. A view of the macrostructure and microstructure of NC11 steel remelted with the use of a laser beam operated at power $P=500 \mathrm{~W}$ and scanning speed $v_{s}=10 \mathrm{~mm} / \mathrm{s}$ : a) macrostructure; b) remelting area; (c-d) HAZ 
a)

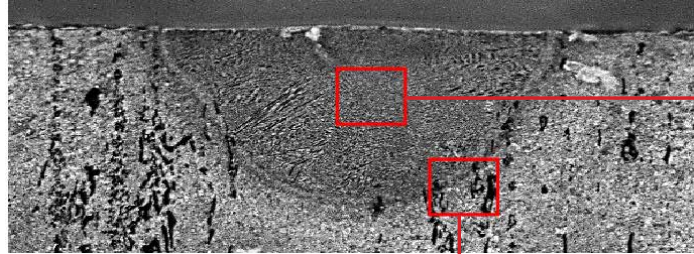

c)

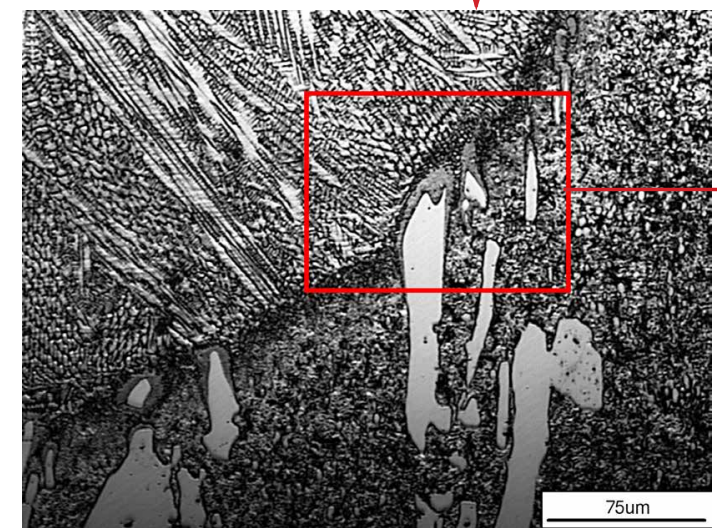

b)

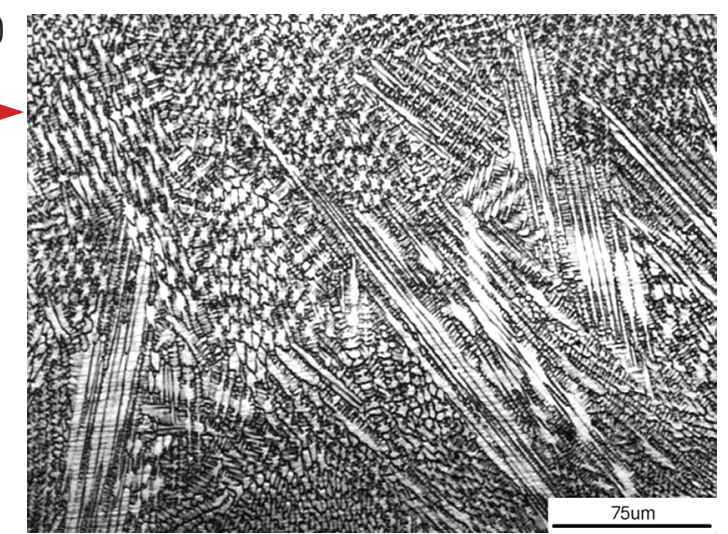

d)

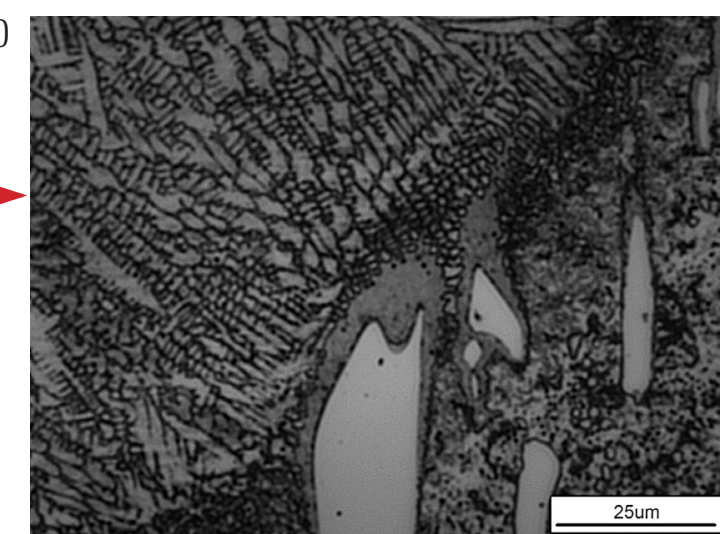

Fig. 6. A view of the macrostructure and microstructure of NC11 steel remelted with the use of laser beam operated at power $P=500$ W and scanning speed $v_{s}=20 \mathrm{~mm} / \mathrm{s}$ : a) macrostructure; b) remelting area; (c-d) HAZ

a)

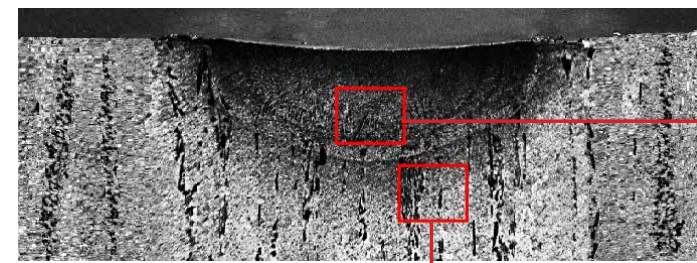

c)

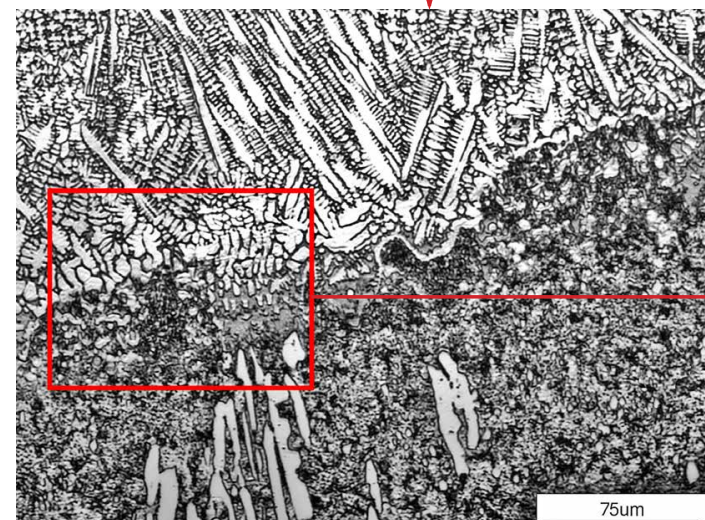

b)

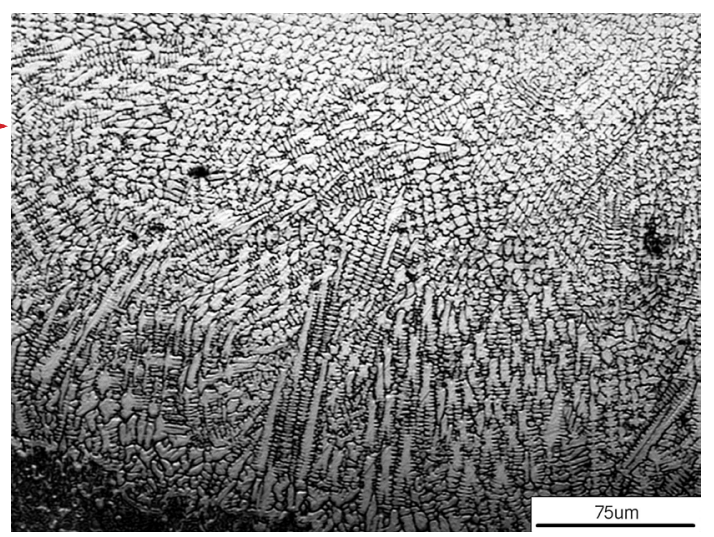

d)

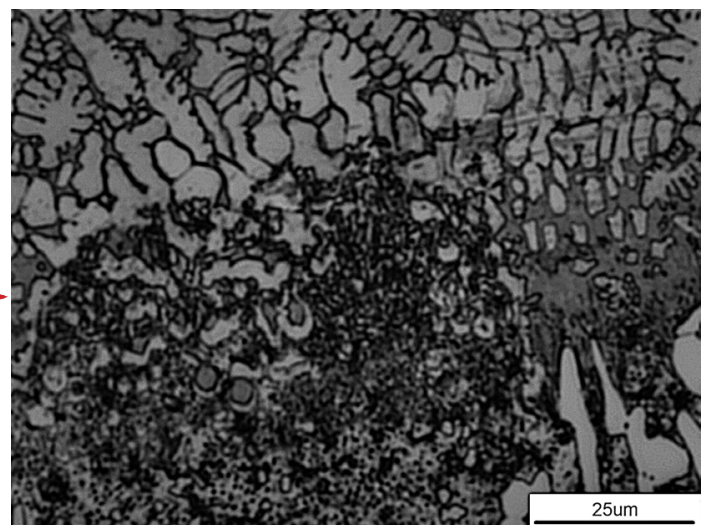

Fig. 7. A view of the macrostructure and microstructure of NC11 steel remelted with the use of laser beam operated at power $P=500 \mathrm{~W}$ and scanning speed $v_{s}=30 \mathrm{~mm} / \mathrm{s}: \mathrm{a}$ ) macrostructure; b) remelting area; (c-d) HAZ 
The measurements were taken with the use of the Vickers method under $\mathrm{HV}_{0.3}$ load. In each of the remelting areas, hardness was measured at least three times. A difference was observed between the hardness of the remelted metal regions and HAZ depending on the laser beam scanning speed. The highest hardness values of 580-643 $\mathrm{HV}_{0.3}$ were observed in the heat-affected zone. In the remelted areas, hardness values ranged from 505 to $552 \mathrm{HV}_{0.3}$. At the adopted parameters of the laser-based remelting process, approximately a 2 - to 2.5 -fold increase in hardness was observed compared to the initial state of the material. Local melting caused the dissolution of alloying elements and chromium carbides in the liquid metal pool. Rapid crystallization meant that the material in the molten area is homogeneous in the form of dendrites with high fragmentation of the precipitates, which promotes an increase in hardness compared to the native material.

The stress value measured on the remelted metal surface increased from 2.5 to 3 times compared to that found in the initial material. The material used for smelting is NC11 steel, which is delivered after plastic working under industrial conditions. Therefore, stresses were observed in the starting material (MR).

Stress measurements provide important information about the service properties of remelted areas as the state of stress is decisive for the nature and type of interaction between friction couples. Such a couple is created, on the one hand, of grains of the refractory material aggregate and, on the other, press mold linings in the course of the process of the fabrication of ceramic bricks (of e.g. fused alumina). Intensity of the abrasive wear process depends on the components of the load force and geometrical parameters characterizing grain shapes, the hardness of the abrasive material, and its state of stress [24-26].

\section{SUMMARY AND CONCLUSIONS}

As a result of the metallographic examination and hardness measurements performed, it can be concluded that in NC11 steel areas remelted with the use of a laser beam, a dendritic microstructure crystallizes with a hardness significantly higher than that of the parent material region. This is due to rapid crystallization which in turn results in its homogenization within the remelting area which favors the emergence of hard dendritic microstructure.

Based on observations made in the course of the performed research and the analysis of the obtained results, it can be concluded that that the laser-remelted areas of NC11 steel:

- are characterized with microstructure differing in a favorable way from that of the parent material,

- show different geometry (width and depth), hardness, and state of stress depending on the adopted parameters of the remelting process,

- show hardness which has increased relative to the parent material, with the maximum observed in the heat-affected zone.
The increased hardness of material in the HAZ compared to the remelted areas stems from the fact that in that very zone, partially unmelted large and very hard carbide precipitates remain, surrounded with hardening-induced structures.

Due to the hardness of the laser, surface hardening should be better than surface melting. However, during surface melting, the structure becomes homogeneous, which is more favorable during operation under wear conditions. The material containing various precipitates during wear promotes cracking and crumbling and pulling out of individual phases. The abrasive wear of a homogeneous material is steady. Therefore, despite the lower hardness of the melting area compared to the HAZ area, laser melting should be a better solution for extending the service life of elements made of NC11 steel.

The increase in hardness and stress values in the remelting area may be favorable to fostering the increased service life and durability of surfaces exposed to abrasive wear. Such a phenomenon occurs in the course of the interaction of aggregate grain edges on mold linings in the course of the press-molding of refractory material stampings.

The possibility of obtaining remeltings characterized with increased hardness on large surfaces of parts and tools made of NC11 steel can be considered as an alternative to the time-consuming and costly heat treatment processes currently applied to press mold components made of the alloy.

The application of the surface remelting process can also be considered a competitive solution to hard-facing with the use of expensive additives aimed at increasing resistance to abrasive wear. Padding welds of that type, in view of the existence of an excess weld metal, must be subject to further machining to obtain the required geometrical dimensions. In the case of laser-induced surface remelting, the face of the weld is flat and there is no excess weld metal since no filler is being added.

\section{Acknowledgements}

The study was carried out with the use of apparatus purchased using funds from the project 'Establishment of the Scientific and Research Inter-University Laboratory in Stalowa Wola', realized as part of the Operational Programme Eastern Poland 2007-2013, Priority axis I 'Modern Economy', Measure 1.3 'Supporting Innovativeness' as per contract No. POPW.01.03.00-18-016/12-00.

\section{REFERENCES}

[1] Orłowicz A., Mróz M., Tupaj M., Kupiec B., Trytek A., Sondej K. \& Kozak L. (2016). A device for evaluation of scratch resistance of die inserts used to fabricate stampings of refractory materials. 15 International Technical Systems Degradation Conference, Liptovský Mikuláš, 30 March - 2 April 2016, vol. 1, 70-73.

[2] Orłowicz A., Mróz M., Tupaj M., Trytek A., Kupiec B., Korzeniowski M., Pająk D., Sondej K. \& Kozak L. (2016). An assessment of appropriateness of the choice of parameters for refractory stampings fabrication process. Archives of Foundry Engineering, 16 (2), 55-60. 
[3] Orłowicz A., Mróz M., Tupaj M., Trytek A., Kupiec B., Korzeniowski M., Cisek Z., Sondej K. \& Kozak L. (2006). Determination of unit pressure force in material volume in the course of refractory stamping press moulding. Archives of Foundry Engineering, 16 (2), 61-68.

[4] Orłowicz A.W., Mróz M., Tupaj M., Trytek A., Kupiec B., Korzeniowski M., Sondej K. \& Kozak L. (2016). The Effect of Carbides Orientation in NC11 Steel on Scratch Susceptibility of Die Inserts Used to Press Stampings for Refractory Shapes. Archives of Foundry Engineering, 16 (2), 95-98.

[5] Orłowicz A., Mróz M., Tupaj M., Kupiec B., Kozak L. \& Kij T. (2017). Application of ceramic coating to improve abrasive wear resistance of die inserts used to press-mould stampings of refractories. Metalurgija, 56 (3-4), 415-418.

[6] Orłowicz A.W., Trytek A. \& Malik J. (2013). Formation of microstructure and service properties of cast iron castings by surface improvement with electric arc plasma. Rzeszów: Oficyna Wydawnicza Politechniki Rzeszowskiej.

[7] Orłowicz A.W., Tupaj. M., Mróz. M., Trytek A. \& Betleja J.J. (2011). Kalorymetr przepływowy do pomiarów cieplnych w procesach spajania. Patent no. 211283, 16.11.2011.

[8] Sondej K., Kozak L., Orłowicz A., Mróz M., Tupaj M., Trytek A., Kupiec B. (2016). A Mould insert with extended service life for press-moulding of stampings. Patent no. 16460035.5-1362, 02.06.2016.

[9] Kim C.K., Lee S. \& Jung J. (2006). Effects of heat treatment on wear resistance and fracture toughness of duo-cast materials composed of high-chromium white cast iron and low-chromium steel. Metallurgical and Materials Transactions A, 37, 633-643.

[10] Chang K.K., Sunghak L. \& Jae-Young J. (2006). Effects of Heat Treatment on Wear Resistance and Fracture Toughness of Duo-Cast Materials Composed of High Chromium White Cast Iron and Low-Chromium Steel. Metallurgical and Materials Transactions A, 37A, March, 633-643.

[11] Pinedo C.E. \& Monteiro W.A. (2001). Surface hardening by plasma nitriding on high chromium alloy steel. Journal of Materials Science Letters, 20, 147-149.

[12] Larson J.A., Fischer R.B. (1982). Precipitation hardening chromium steel casting alloy U.S. Patent Apr. 27, 4,326,885.

[13] Adetunji O.R., Musa A.A. \& Afolalu S.A. (2015). Computational Modelling of Chromium Steel in High Temperature Applications. International Journal of Innovation and Applied Studies, 12 (4), 1015-1021.
[14] Tillmann W., Schaak C., Hagen L., Mauer G. \& Matthäus G. (2019). Internal Diameter Coating Processes for Bond Coat (HVOF) and Thermal Barrier Coating (APS) Systems. Journal of Thermal Spray Technology, 28 (1-2), 233-241.

[15] Seshadri R.C. \& Sampat S. (2019). Characteristics of Conventional and Cascaded Arc Plasma Spray-Deposited Ceramic Under Standard and High-Throughput Conditions. Journal of Thermal Spray Technology, 28 (4), 690-705.

[16] Yingchun Xie, Chaoyue Chen, Marie-Pierre Planche, Sihao Deng, Renzhong Huang, Zhongming Ren \& Hanlin Liao. (2019). Strengthened Peening Effect on Metallurgical Bonding Formation in Cold Spray Additive Manufacturing. Journal of Thermal Spray Technology, 28 (4), 769-779.

[17] Aghasibeig M., Tarasi F., Lima R.S., Dolatabadi A. \& Moreau C. (2019). A Review on Suspension Thermal Spray Patented Technology Evolution. Journal of Thermal Spray Technology, 28 (7), 1579-1605.

[18] Nowotny S., Scharek S., Beyer E. \& Richter K.H. (2007). Laser Beam Build-Up Welding: Precision in Repair, Surface Cladding, and Direct 3D Metal Deposition. Journal of Thermal Spray Technology 16 (3), 344-348.

[19] Orłowicz A. \& Mróz M. (2003). Microstructure and fatigue strength of A 356 alloy castings refined on the surface by rapid crystallization. Zeitschrift für Metallkunde, 94 (12), 1320-1326.

[20] Orłowicz A. \& Trytek A. (2003). Effect of rapid solidification on sliding wear of iron castings. Wear, 254, 154-163.

[21] Orłowicz A. \& Trytek A. (2003). A Susceptibility of iron castings to heat absorption from electric arc and to hardened-layer shaping. Metallurgical and Materials Transactions, 34A, 2973-2984.

[22] Mróz M., Orłowicz A. \& Tupaj M. (2013). Stress-rupture Tests of MAR-M-509 Cobalt Alloy Improved by Rapid Solidification. Archives of Foundry Engineering, 13 (1), 117-120.

[23] PN-EN ISO 4957:2018-09 - Stale narzędziowe.

[24] Hebda M. \& Wachal A. (1980). Trybologia. Warszawa: WNT, internet edition by: Polskie Towarzystwo Trybologiczne 2005, http://www.tribologia.eu/ptt/try/tr.htm

[25] Nastaj T. (2003). Badanie odporności na zużycie ścierne powłok napawanych stopami na bazie niklu. Eksploatacja i Niezawodność, 2, 49-51.

[26] Pytko S. (1982). Problemy wytrzymałości kontaktowej. Warszawa: PAN. 